\title{
UKM “BANGKIT": STRATEGI PENGUATAN EKONOMI DAN KEBANGKITAN DI ERA KENORMALAN BARU COVID-19
}

\section{UKM “BANGKIT": A STRATEGY FOR STRENGTHENING ECONOMICS AND REVIVAL DURING NEW NORMAL ERA OF COVID-19}

\author{
Surahma Asti Mulasari ${ }^{1)^{*}}$, Fatwa Tentama ${ }^{2)}$, Tri Wahyuni Sukesi ${ }^{3)}$, Sulistyawati ${ }^{4)}$, \\ Lu'lu' Nafiati $^{\text {5) }}$, Herman Yuliansyah ${ }^{6}$, Siti Kurnia Widi Hastuti ${ }^{7)}$, Rokhmayanti ${ }^{8)}$ \\ ${ }^{1)}$ Fakultas Kesehatan Masyarakat, Universitas Ahmad Dahlan, Yogyakarta, Indonesia \\ email: surahma.mulasari@ikm.uad.ac.id \\ ${ }^{2)}$ Fakultas Psikologi, Universitas Ahmad Dahlan, Yogyakarta, Indonesia \\ ${ }^{3-4)}$ Fakultas Kesehatan Masyarakat, Universitas Ahmad Dahlan, Yogyakarta, Indonesia \\ ${ }^{5)}$ Fakultas Ekonomi, Universitas Ahmad Dahlan, Yogyakarta, Indonesia \\ ${ }^{6)}$ Fakultas Teknologi Industri, Universitas Ahmad Dahlan, Yogyakarta, Indonesia \\ J1. Prof. Dr. Soepomo Janturan Warungboto, Yogyakarta, Indonesia \\ ${ }^{7-8)}$ Fakultas Kesehatan Masyarakat, Universitas Ahmad Dahlan, Yogyakarta, Indonesia
}

\section{ABSTRAK}

Latar belakang: Usaha Kecil Menengah (UKM) Bangkit merupakan sebuah unit usaha yang didirikan oleh organisasi Kreatif dan Wisata Lokal yang ada di Desa Ngoro-oro. UKM Bangkit memiliki unit usaha kuliner berupa kripik dari sayuran, olahan singkong, olahan pisang, dan olahan potensi lokal lainnya, serta unit pariwisata. UKM Bangkit dibentuk untuk mewadahi kelompok produktif di Desa Ngoro-oro dengan harapan dapat saling mendukung untuk menguatkan ekonomi masyarakat di era kenormalan baru Covid-19.

Tujuan: Membangkitkan kembali perekonomian di Desa Ngoro-oro yang terdampak selama pandemi Covid-19 baik dari pemasaran, manajerial, modal, optimalisasi pemasok bahan baku pembuatan produk, pembuatan jejaring pemasaran serta pelatihan Protokol K3 Covid-19 dan risikonya dalam menjalankan aktivitas ekonomi di era adaptasi Covid-19.

Metode: Program UKM Bangkit ini dilaksanakan dengan kerjasama antara tim pengusul, mahasiswa dan mitra (Pemerintah Desa Ngoro-oro). Metode yang dilakukan adalah dengan pelatihan motivasi berwirausaha, penyuluhan Adaptasi Covid-19 di sektor ekonomi, dan Focus Grup Discussion (FGD) untuk membuat sistem jejaring produsen, pemasok bahan baku dan pemasaran. Program terjadwal selama tiga bulan dari Oktober - Desember 2020. Pengabdian Kepada Masyarakat ini merupakan bagian dari kegiatan Hibah UKM Indonesia Bangkit 2020 yang didanai oleh RISTEK-BRIN.

Hasil: Kegiatan yang dilaksanakan di Desa Ngoro-oro menghasilkan terbentuknya UKM Bangkit yang dikelola oleh masyarakat di tingkat desa. Dengan adanya potensi bahan baku yang ada di Desa Ngoro-oro mampu dimanfaatkan menjadi makanan yang dapat dijual di sekitar wilayah Desa Ngoro-oro serta sebagai pendukung bidang kuliner Desa wisata Ngorooro. UKM Bangkit menyediakan jejaring beberapa toko/warung yang bisa digunakan untuk menitipkan barang dagangannya di sekitar Patuk Gunungkidul.

Dampak: Masyarakat menjadi lebih bersemangat untuk berkegiatan di Era Adaptasi Covid19, masyarakat bisa kembali produktif dengan adanya kegiatan di UKM Bangkit serta dapat menambah penghasilan masyarakat.

Kata kunci: Objek wisata, UKM, Kuliner, Covid-19, Adaptasi

\section{ABSTRACT}

Background: "Bangkit" Small and Medium Enterprises (UKM) is a business unit established by the Creative and Local Tourism organization in Ngoro-oro Village, Gunungkidul District. UKM Bangkit has a culinary business unit in the form of chips from vegetables, cassava, bananas and other local potentials and a tourism unit. UKM Bangkit was developed to accommodate productive groups in Ngoro-oro with an expectation to support each other aimed to strengthen the community economy in the new era of Covid-19. 
Purpose: To revive the economy in Ngoro-oro Village which was affected by the Covid-19 pandemic - in term of marketing, managerial, capital, optimization of suppliers of raw materials for product manufacture, creation of marketing networks, training on the Covid-19 health protocol and the risks involved in carrying out economic activities in the era of Covid19 adaptation.

Methods: The UKM Bangkit program is implemented in collaboration between the team, students and partners (Ngoro-oro Village Government). The method used to reach the aim is entrepreneurial motivation training, counselling on Covid-19 adaptation in the economic sector, and Focus Group Discussions (FGD) to create a network system for producers, suppliers of raw materials and marketing. The program is scheduled for three months from October to December 2020. This community service is part of the 2020 grant namely Bangkit Indonesia Bangkit for UKM that funded by RISTEK-BRIN.

Result: The activities carried out in Ngoro-oro Village resulted in the formation of UKM Bangkit which was managed by the community at the village level. With the potential for the existing raw materials in Ngoro-oro Village, it can be used as food that can be sold around the Ngoro-oro Village area and as a supporter of the culinary field of the Ngoro-oro tourism village. UKM Bangkit provides a network of several shops that can be used to deposit their merchandise around Patuk Gunungkidul.

Impact: The community becomes more enthusiastic about doing activities in the Covid-19 adaptation era, the community can return to productivity with the activities at UKM Bangkit and can increase people's income.

Keywords: Tourism, UKM, Culinary, Covid-19, Adaptation

\section{PENDAHULUAN}

Dusun Gembyong merupakan desa

perbatasan dengan Sleman. Dusun

Gembyong dulunya memiliki tingkat

perekonomian yang rendah jika

dibandingkan dengan dusun lainnya di Desa

Ngoro-oro. Dusun Gembyong memiliki luas

wilayah 62.45 ha dengan jumlah penduduk 276 jiwa yang terbagi dalam 5 RT dan 1 RW

(Desa Ngoro-oro). Mayoritas warga desa tersebut berprofesi sebagai petani lahan kering dan semusim. Dusun Gembyong merupakan wilayah pedesaan yang memiliki potensi lokal berupa bambu dan kayu-kayu besar. Potensi budaya yaitu seni karawitan. Mayoritas warga beragama Islam. Jarak Mitra terhadap Kampus 3 UAD, Janturan, Umbulharjo, Yogyakarta diperkirakan +21 $\mathrm{km}[1]$.

Desa Ngoro-oro memiliki banyak potensi wisata. Selain kegiatan wisata di
Jurug Gedhe, juga memiliki potensi lain yaitu wilayah persawahan yang asri sebagai spot foto pedesaan di saat musim bercocok tanam serta adanya tebing batu putih yang saat ini menjadi icon menarik bagi para pesepeda (cycling). Di sisi lain sebagai aspek pelengkap pariwisata Desa ini memiliki beberapa kuliner khas diantaranya adalah soto dan sego gumbrek yang sedang dirintis menjadi kekhasan kuliner lokasi ini. Potensi tersebut pengelolaannya di bawah Badan Usaha Milik Desa (BUMDES), sehingga dapat berfungsi menjadi sumber pendapatan bagi desa. Di Desa Ngoro-oro ada rintisan Usaha Kecil Menengah (UKM) baru disebut UKM Bangkit.

Usaha Kecil Menengah (UKM) adalah jenis usaha yang harus dapat bertahan pada kondisi sulit dengan menerapkan kegiatan inovasi yang berbasis pasar konsumen [2]. Melihat keadaan kesejateraan UKM saat ini

http://logista.fateta.unand.ac.id 
yang diukur dari parameter pendapatan, pelaku usaha dituntut untuk harus mampu menyiasati perubahan lingkungan usaha dengan kebiasaan konsumen. Beberapa metode pemerintah untuk kegiatan dari rumah menjadi sasaran perubahan UKM melakukan kegiatan yang dapat menunjang usaha [3].

Para pelaku UKM perlu memperhatikan serta mampu beradaptasi dengan adanya kejadian yang luar biasa ini. UKM mampu beradaptasi dalam penggunaan teknologi yang dituntut untuk melakukan penjualan daring serta mengelola keuangan dengan kondisi yang sangat minim. Jika pelaku usaha tidak memiliki dana darurat, sehingga dalam pengelolaan keuangannya baik untuk menjual produk maupun mempertahankan produknya, maka mudah sekali UKM tersebut mengalami kebangkrutan. Ancaman krisis yang terjadi di masa pandemi ini mendorong UKM untuk mampu berubah ke penjualan daring. Kondisi ini memaksa mau tidak mau dari UKM kecil sampai besar mampu menemukan cara-cara yang baru dan strategis menemukan semua peluang yang ada [4].

Setelah pandemi ini berakhir, kita akan memulai kehidupan normal yang baru, kehidupan yang tidak akan sama sebelum Covid-19 ini merebak. Hal ini disebabkan karena adanya alasan kesehatan dan keselamatan diri. Dalam bidang ekonomi, dampak yang lebih besar akan sangat terasa, misalnya masyarakat akan cenderung untuk berbelanja secara online, masyarakat lebih nyaman untuk membuat dan menyiapkan makanan mereka sendiri dengan pertimbangan lebih higienis.

Perubahan perilaku masyarakat tersebut mendorong peningkatan permintaan bisnis untuk menyiapkan makanan cepat saji yang sehat di rumah seperti racikan sayur dan daging yang hanya tinggal memanaskan dan makanan beku. Hal ini akan diikuti dengan meningkatnya teknologi yang mendukung makanan sehat dan juga aplikasi memasak akan lebih banyak dibutuhkan oleh para pemasak pemula. Industri pariwisata akan mengalami hal yang sama dan akan mengutamakan penerapan standar protokol kesehatan dan standar keamanan yang dipandang memadai untuk tetap menjaga kenyaman para wisatawan berkunjung ke obyek wisata.

Kehidupan new normal inilah yang sangat menarik untuk dibahas khususnya dalam melihat kesiapan pemerintah dan stakeholder menghadapi pemulihan pariwisata di masa pandemi. Alternatif pilihan berwisata yang berbeda harus dipikirkan supaya obyek wisata tetap menjadi magnet bagi wisatawan domestik maupun mancanegara tentu dengan tidak mengabaikan protokol kesehatan [5].

Di masa pandemi Covid-19 ini, industri pariwisata di desa Ngoro-oro yaitu Jurug Gedhe tidak beroperasi, dari Maret - Juli 2020 saat pendemi Covid-19 ini karena tidak ada wisatawan sama sekali. Selain itu, adanya Pembatasan Sosial Berskala Besar (PSBB) menjadikan unit usaha makanan tidak mendapatkan pesanan makanan. Anggota UKM dan warga yang menitipkan 
makanan dan jajanan di toko-toko/ warung kehilangan sumber penghasilan. Kebangkitan sektor pariwisata dan industri kuliner pada era kenormalan baru ini sangat ditunggu oleh UKM di Desa Ngoro-oro, terutama oleh UKM Bangkit yang memang dibentuk untuk meningkatkan geliat ekonomi di era pandemi Covid19.

\section{METODE PELAKSANAAN KEGIATAN}

Program UKM Bangkit ini dilaksanakan dengan kerjasama antara tim pengusul, mahasiswa dan mitra Program UKM Indonesia Bangkit 2020. Mitra dalam penelitian ini adalah Desa Ngoro-oro beserta UKM didalam wilayan Desa Ngoro-oro. Kegiatan ini dilakukan dengan beberapa tahapan yaitu identifikasi kebutuhan, perancangan, pembuatan, pendampingan operasional, dan evaluasi pelaksanaan progam. Kegiatan pelatihan dilakukan secara bertahap mulai dari bulan Oktober Desember 2020. Beberapa kegiatan yang sudah dilaksanakan untuk mewujdukan perbaikan ekonomi Desa Ngoro-oro melalui UKM Bangkit adalah:

1. Koordinasi dan sosialisasi

2. Pelatihan keuangan penggiat wisata

3. Pembuatan jejaring produsen dan jejaring pemasaran (warung yg bisa menjualkan produk)

4. Pelatihan kewirausahaan bagi anggotan UKM Bangkit

5. Pelatihan keuangan bagi pengurus UKM Bangkit

6. Pelatihan Web bagi pengurus UKM bangkit

\section{HASIL DAN PEMBAHASAN}

Kegiatan yang dilaksanakan di Desa Ngoro-oro mendorong terbentuknya UKM Bangkit yang dikelola oleh masyarakat sekitar. Usaha Kecil dan Menengah (UKM) adalah usaha produktif yang dimiliki perorangan maupun badan usaha yang telah memenuhi kriteria sebagai usaha mikro, seperti diatur dalam Peraturan PerundangUndang No. 20 tahun 2008 [6].

Dengan dukungan semua pihak yang terlibat UKM Ngoro-oro ini dapat menjadi tombak perubahan perekonomian masyarakat di Desa Ngoro-oro. Pembentukan Pengurus UKM Bangkit terdiri dari pemilik UKM di desa Ngoro-oro dan didukung oleh pemuda desa yang memiliki potensi dalam penggunaan IT. UKM Bangkit dapat membantu masyarakat untuk memasarkan barang dagangan masyarakat serta membantu menambah penghasilan masyarakat.

Potensi bahan baku yang dihasilkan di Desa Ngoro-oro sangat beragam. Diantaranya yaitu pisang (pisang buah dan pisang yang dapat digunakan untuk pembuatan keripik), singkong (tersedia tergantung musim), talas (tersedia tapi tidak memenuhi kebutuhan pembuatan keripik), intip (banyak masyarakat yang menanak nasi dengan cara di liwet sehingga menghasilkan intip), tempe (bahan baku kedelai dibeli dari daerah lain), jagung, kacang tanah, rempahrempah, dan hasil ternak (ayam). Dengan adanya potensi bahan baku yang sangat beragam di Desa Ngoro-oro dapat menambah produktifitas masyarakat dalam 
memanfaatkan bahan tersebut menjadi barang yang dapat dijual dan menjadi makanan ciri khas Desa Ngoro-oro.

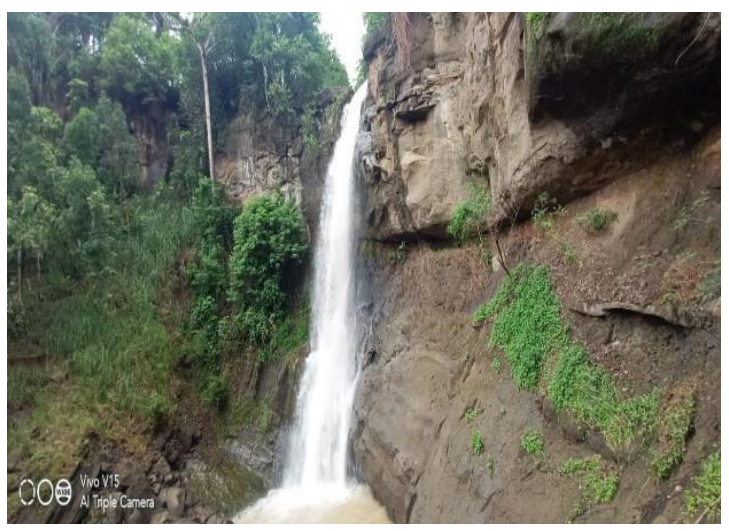

Gambar 1. Wisata Alam Jurug Gedhe

Selain itu, adanya obyek wisata Jurug Gedhe mampu memfasilitasi masyarakat untuk membuka usaha berupa angkringan maupun warung-warung yang menjual makanan dan oleh-oleh. Dengan adanya UKM di Desa Ngoro-oro juga membantu masyarakat yang ingin menjual hasil dangagannya. Produk yang dihasilkan oleh UKM berupa Nasi kucing, Aneka sate, Gorengan, Wedang jahe, Wedang uwuh, Kopi, Keripik pisang, Keripik singkong, dan masih banyak lagi.

UKM Bangkit menyediakan beberapa toko/warung yang bisa digunakan untuk menitipkan barang dagangannya. Masyarakat dapat menitipkan produk dagangannya ke angkringan maupun beberapa warung milik yang ada disekitar obyek wisata Jurug Gedhe. Masyarakat merasa terbantu dengan adanya progam UKM di Desa Ngoro-oro untuk menambah penghasilan.

Dampak yang dirasakan oleh masyarakat yaitu masyarakat yang memiliki usaha kecil merasa terwadahi dengan adanya UKM
Bangkit. Masyarakat sekitar dapat menitipkan barang dagangannya di warungwarung yang telah bekerjasama dengan UKM Bangkit. Masyarakat memanfaatkan media penjualan on line sehingga berdampak pada penjualan yang dilakukan tidak hanya mengandalkan masyarakat lokal sehingga area pemasaran lebih luas. Serta memaksimalkan penggunaan bahan baku lokal kerena harapan adanya UKM bangkit bahan baku yang digunakan dari masyarakat lokal. Banyaknya bahan baku yang ada di Desa Ngoro-oro menjadikan masyarakat menjadi lebih kreatif dalam mengolahan bahan makanan menjadi makanan yang unik dan dapat menjadi ciri khas Desa Ngoro-oro.

Untuk mengembangkan usaha yang dikelola masyarakat tidaklah selalu berjalan lancar. Banyak hambatan yang dialami masyarakat dalam mengelola makanan. Diantaranya yaitu tidak semua bahan baku tersedia di desa Ngoro-oro, beberapa bahan baku tersedia tergantung pada musim, SDM belum memiliki ketrampilan memanfaat IT dan social media untuk media pemasaran on line, serta para pelaku UKM belum memiliki ketrampilan majemen keuangan/ akuntansi keuangan. Hal itu sangat mempengaruhi naik turunnya produksi makanan. Masyarakat harus mencari alternatif lain agar produksi dapat terus berjalan ketika bahan baku sulit didapatkan.

Adanya pandemic Covid-19 di tahun ini hampir mematikan seluruh perekonomian dunia dan menjadikan tantangan yang harus dihadapi oleh UKM semakin berat. Hampir 
semua teknik pemasaran yang digunakan tidak memberikan dampak terhadap kinerja pemasaran. Kinerja pemasaran terus semakin menurun, khususnya di rentang bulan Maret sampai Mei 2020 [7].

Usaha kecil dan menengah (UKM) berada di garis depan guncangan ekonomi yang disebabkan oleh pandemi COVID-19. Langkah-langkah penguncian (lockdown) telah menghentikan aktivitas ekonomi secara tiba-tiba, dengan penurunan permintaan dan mengganggu rantai pasokan di seluruh dunia [8].

Salah satu dampak pandemic COVID-19 yang telah menghantam UKM adalah sebanyak 1.785 koperasi dan 163.713 pelaku usaha mikro kecil menengah terdampak pandemi virus corona (Covid-19). Kebanyakan koperasi yang terkena dampak Covid-19 bergerak pada bidang kebutuhan sehari-hari, sedangkan sektor UKM yang paling terdampak yakni makanan dan minuman. Para pengelola koperasi merasakan turunnya penjualan, kekurangan modal dan terhambatnya distribusi. Sementara itu, sektor UKM yang terguncang selama pandemi Covid-19, selain makanan dan minuman, adalah industri kreatif dan pertanian [8].

Namun, dengan semangat para masyarakat untuk memajukan UKM di desa Ngoro-oro serta dukungan dan komitmen kepala desa untuk memajukan UKM dan meningkatkan ekonomi masyarakatnya, UKM di Desa Ngoro-oro tetap berjalan dan semakin maju. Kini Desa Ngoro-oro memiliki food court yang bisa digunakan untuk menjual hasil UKM. Dukungan masyarakat dalam mendukung gerakan belanja pada warung tetangga menjadikan UKM Bangkit terus dapat berjalan serta dapat membantu masyarakat yang menitipkan barang dagangannya di UKM Bangkit. Masyarakat juga sudah memiliki jadwal rutin pertemuan antar UKM yang difasilitasi oleh Desa. Selain itu adanya potensi tempat wisata yang dapat dikembangkan di Desa Ngoro-oro juga menambah daftar warung/toko yang dikelola oleh UKM Bangkit untuk menjajakan hasil kreativitas masyarakat di Desa Ngoro-oro

\section{KESIMPULAN}

Hasil penelitian ini menyimpulkan bahwa dengan adanya UKM Bangkit yang ada di desa Ngoro-oro mampu membantu masyarakat untuk mengembangkan usaha kecil yang dikelola masyarakat serta mampu mengenalkan bahan baku lokal yang dimiliki Desa Ngoro-oro.

\section{UCAPAN TERIMAKASIH}

Terimakasih kami ucapkan kepada segala pihak yang telah membantu mensukseskan Progam Pengabdian Kepada Masyarakat, semoga dapat bermanfaat dan memberikan perubahan ke arah yang lebih baik. Pihak-pihak yang terlibat tersebut adalah : Kementerian Riset dan Teknologi/ BRIN, Pemerintah Desa Ngoro-oro, Dinas Pariwisata Kabupaten GunungKidul, Masyarakaat Desa Ngoro-oro, Mitra UKM Wisata Jurug Gedhe, dan Fakultas Kesehatan Masyarakat UAD 


\section{REFERENSI}

[1] Gunungkidul, D. P. K. 2020. Gunung Gentong. Destinasi Wisata Gunung Kidul.

https://wisata.gunungkidulkab.go.id/202 0/07/20/gunung-gentong/. Diakses tanggal 20 Juli 2020.

[2] Kristinae, V. and Sahay, M. 2019. Pengaruh Social Media, Learning Orientation Dan Market Orientation Kalimantan Tengah. Jurnal Binawakya, 14(2): 1959-1966

[3] Darung, F. and Kristinae, V. 2020. Arsitektur Strategi Bisnis Dalam Meningkatkan Kesejahteraan Ukm Makanan Kecil Pada Masa Covid-19 Di Kalimantan Tengah. Jurnal Binawakya, 15(1): 3815-3822.

[4] Susanti, A., Istiyanto, B. and Jalari, M. 2020. Strategi UKM pada Masa Pandemi Covid-19. Karya Ilmiah Pengabdian
Masyarakat, 1(2): 67-74

[5] Paramita, I. B. G. and Putra, I. G. G. P. A. 2020. New Normal Bagi Pariwisata Bali Di Masa Pandemi Covid 19. Pariwisata Budaya: Jurnal Ilmiah Pariwisata Agama dan Budaya: 57-65. doi: $10.36275 / \mathrm{mws}$

[6] Farizki, F. I. et al. 2020. Penyuluhan UKM Di Era New Normal Dengan Memprioritaskan Ekonomi Digital Marketing. Jurnal Pengabdian Masyarakat Berkemajuan, 4(1): 620 623

[7] Anjaningrum, W. D. 2020. Efektivitas Digital Marketing Dan Networks Dalam Mendongkrak Kinerja Pemasaran Ukm Di Masa Pandemi Covid-19. Jurnal Senabisma, 6(7): 50-61.

[8] Thaha, A. F. 2020. Dampak Covid-19 Terhadap UKM Di Indonesia. Jurnal Brand, 2(1): 147-153 